\title{
MENINGKATKAN KINERJA KARYAWAN MELALUI KETERIKATAN, BUDAYA ORGANISASI, DAN GAYA KEPEMIMPINAN
}

\author{
Sukaris \\ Mayang Putri Prathiwi \\ Budiyono Pristyadi \\ Fakultas Ekonomi dan Bisnis, Universitas Muhammadiyah Gresik \\ email: sukaris21@umg.ac.id
}

\begin{abstract}
The purpose of this research is to examine the influence of employees' attachment, organizational culture, and leadership style on the performance of permanent employees in Koperasi Warga Semen Gresik. This study uses quantitative method with the number of samples of 108 respondents. The data source used is the primary data obtained by spreading the questionnaire. The analytical method used is multiple linear regression tested with IBM Statistics 21. The results showed that, partial test results from employee engagement variables and organizational culture have a significant effect on the performance of employees of Koperasi Warga Semen Gresik, while for leadership style variables have no significant effect on employee performance.
\end{abstract}

Keywords: employee engagement, organizational culture, leadership style, employee performance

\section{PENDAHULUAN}

Era industry 4.0 saat ini telah memberikan perkembangan pada disrupsi digital dalam aktivitas bisnis, sehingga menjadikan perusahaan pada posisi sulit untuk melakukan kontrol pada lingkungan eksternal sehingga situasi menjadi tidak mudah diprediksi, resiko yang sulit di kelola dan juga ketidakpastian.

Perusahaan dalam menjalankan usaha baik perusahaan jasa maupun perusahaan manufaktur membutuhkan sumber daya manusia yang berkompeten dan memiliki kontribusi yang baik untuk perusahaan. Perusahaan harus mampu menyusun berbagai macam strategi manajemen untuk mencapai sasaran dan tujuan yang diharapkan. Perusahaan harus memperhatikan faktor eksternal seperti sosial budaya, politik dan persaingan, serta teknologi. Selain dari faktor eksternal, perusahaan juga harus memperhatikan faktor internal dengan maksud untuk mengetahui sejauh mana perusahaan mampu mencapai tujuan yang diharapkan dari seberapa besar perusahaan memenuhi tuntutan lingkungan (Rivai \& Sagala, 2011:547).

Pada kondisi tersebut perusahaan harus memiliki kecepatan dalam beradaptasi dengan perubahan yang ada sehingga keunggulan, kinerja perusahaan maupun kinerja karyawan dapat terjaga dan meningkat (Sukaris, 2018). Namun demikian sisi positifnya adalah memunculkan tantangan baru juga memberikan sebuah peluang bagi perusahaan untuk membuat konsep manajemen yang efektifefisien melalui manajemen sumberdaya-manusia (Alkusani \& Sukaris, 2019).

Sumber daya manusia menjadi aset yang unik bagi perusahaan karena merupakan salah satu aset yang bernyawa dalam menjalankan kegiatan baik manajerial maupun kegiatan operasional perusahaan sehingga memerlukan perhatian khusus agar terciptanya hubungan yang positif antara karyawan dengan perusahaan yang diwujudkan melalui kinerja.

Kinerja merupakan hasil yang telah dicapai atau melampaui dari standar yang dilakukan karyawan dalam pekerjaannya berdasarkan apa yang telah ditentukan tersebut. Kinerja karyawan sendiri banyak dipengaruhi oleh beberapa faktor baik yang berasal dari individu maupun luar individu seperti keterikatan karyawan, budaya organisasi dan juga gaya kempimpinan Handoyo dan Setiawan (2017); Joushan dkk. (2015) ; Bakara dan Suskiswo (2015).

Adanya keterikatan karyawan dengan perusahaan dapat menunjukkan seberapa kuat budaya organisasi yang diterapkan dalam koperasi. Nilai dalam budaya organisasi dapat dijadikan sebagai acuan perilaku manusia dalam organisasi 
p-ISSN 1693-1378

e-ISSN 2598-9952
Meningkatkan Kinerja Karyawan Melalui... (Sukaris, Mayang Putri Prathiwi, Budiyono Pristyadi) yang berorientasi pada pencapaian tujuan dan hasil kinerja yang ditetapkan. Budaya organisasi merupakan suatu sistem berbagai arti yang dilakukan oleh semua anggota yang membedakan satu organisasi dengan organisasi lain sehingga menjadi ciri khas bagi masing-masing organisasi.

Keterikatan karyawan dan budaya organisasi yang baik juga dapat mencerminkan peran dari seorang pemimpin dalam memimpin perusahaan maupun koperasi. Seorang pemimpin tidak terlepas dari bagaimana model atau gaya kepemimpinan yang diterapkan untuk mempengaruhi karyawan atau bawahan agar memberikan kinerja terbaiknya bagi perusahaan.

Penelitian terdahulu yang dilakukan oleh Handoyo dan Setiawan (2017) yang berjudul pengaruh employee engagement terhadap kinerja karyawan pada PT Tirta Rejeki Dewata dengan jumlah sampel sebanyak 50 orang, hasil penelitian menunjukkan bahwa employee engagement berpengaruh positif dan signifikan terhadap kinerja karyawan. Penelitian Joushan dkk., (2015) dengan judul penelitian pengaruh budaya organisasi dan employee engagement terhadap kinerja karyawan pada PT PLN (Persero) area Bekasi dengan sampel sebanyak 73 karyawan, hasil penelitian menunjukkan bahwa budaya organisasi berpengaruh signifikan terhadap employee engagement dan kinerja karyawan, namun employee engagement tidak berpengaruh signifikan terhadap kinerja.

Penelitian Khairizah (2015) dengan judul penelitian pengaruh gaya kepemimpinan terhadap kinerja karyawan studi pada karyawan Perpustakaan Universitas Brawijaya Malang dengan sampel sebanyak 55 orang karyawan tetap, hasil penelitian menunjukkan bahwa gaya kepemimpinan secara bersama-sama memiliki pengaruh positif dan signifikan terhadap kinerja karyawan perpustakaan Universitas Brawijaya Malang.

\section{Tinjauan Literatur}

Keterikatan Karyawan

Robbins and Judge (2009:103) mengatakan employee engagement adalah keterlibatan individu dengan kepuasan dan antusiasme untuk pekerjaan yang dilakukan. Keterikatan (engagement) karyawan dianggap sebagai energi dan motivasi positif yang dimiliki karyawan sehingga membantu perusahaan untuk mencapai tujuan (Schiemann, 2011:30).

Employee engagement (keterikatan karyawan) dapat dihubungkan dengan kesuksesan dan beragam konsekuensi bisnis yang lebih besar seperti karyawan lebih gigih dalam berupaya, kinerja yang lebih baik, kualitas yang lebih tinggi dan menurunnya tingkat turnover karyawan (Akbar, dalam Rustono dan Akbari, 2015;1173).

Siddhanta dan Roy (2010:171) menyatakan bahwa "employee engagement dapat menciptakan kesuksesan bagi perusahaan yang berkaitan dengan kinerja karyawan, produktifitas, keselamatan kerja, kehadiran dan retensi, kepuasan pelanggan, loyalitas pelanggan, dan profitabilitas" maka kinerja karyawan menjadi salah satu hal yang dapat menciptakan tingginya employee engagement (keterikatan karyawan).

Keterikatan karyawan terbagi menjadi 3 dimensi menurut Schaufeli dan Bakker (dalam Akbar, 2013:13) yaitu vigor (semangat), dedication (dedikasi) dan absorption penyerapan) dengan 7 indikator dari keterikatan karyawan menurut Anita (dalam Handoyo dan Setiawan 2017:168) yaitu lingkungan kerja, kepemimpinan, tim dan hubungan rekan kerja, pelatihan dan pengembangan karir, kompensasi, kebijakan organisasi, dan kesejahteraan kerja.

Hubungan keterikatan karyawan terhadap kinerja karyawan dapat dijelaskan bahwa Karyawan pada saat bekerja tidak hanya berfokus pada gaji atau promosi akan tetapi bekerja untuk mencapai tujuan organisasi (Kruse, 2012:698). Karyawan yang memiliki hubungan baik atau terikat dengan perusahaan menjadi salah satu faktor keberhasilan perusahaan.

Menurut Akbar (dalam Rustono dan Akbary, 2013:1173), employee engagement (keterikatan karyawan) dapat dihubungkan dengan kesuksesan perusahaan seperti kualitas lebih tinggi, rendahnya tingkat turnover, dan kinerja karyawan menjadi lebih baik. Dengan demikian, keterikatan karyawan memiliki hubungan yang bersifat positif terhadap kinerja karyawan.

\section{Budaya Organisasi}

Budaya yang kuat dapat dijadikan sebagai acuan untuk mengarahkan perilaku individu atau karyawan agar dapat melakukan pekerjaan dengan baik sehingga karyawan perlu memahami budaya yang berlaku dalam perusahaan dan bagaimana budaya dapat diimplementasikan. Menurut Mangkunegara (dalam Zahriyah dkk, 2015) mengatakan bahwa budaya organisasi merupakan pandangan atau peraturan yang sudah diyakini karyawan dalam perusahaan, dimana aturan tersebut harus ditaati untuk kepentingan bersama. Robbins and Judge, 2015;355 mendefinisikan 
budaya organisasi sebagai sistem berbagi arti yang dilakukan oleh semua anggota yang membedakan satu organisasi dengan organisasi lain.

Beberapa karakteristik budaya organisasi dari penelitian Zahriyah, dkk (2015) terbagi menjadi 4 yaitu norma, nilai dominan, aturan, dan iklim organisasi. Menurut Robbins and Judge $(2015 ; 335)$ menyebutkan 7 karakteristik utama yang dapat dijadikan indikator dari budaya organisasi, diantaranya inovasi dan pengambilan resiko, memperhatikan detail, orientasi pada hasil, orientasi pada orang, orientasi pada tim, keagresifan, dan stabilitas.

Dapat disimpulkan bahwa budaya organisasi merupakan nilai- nilai dan norma yang diterapkan dalam perusahaan dengan tujuan untuk mempengaruhi karakteristik atau perilaku karyawan agar dapat mengerjakan tugas dengan tepat waktu serta bagaimana karyawan mampu menghadapi masalah internal atau eksternal perusahaan untuk bersama-sama mencapai tujuan organisasi atau perusahaan.

Hubungan budaya organisasi terhadap kinerja karyawan, Menurut Robbins and Judge (2015;355) budaya organisasi merupakan sistem berbagi arti yang dilakukan semua anggota dan membedakan satu organisasi dengan organisasi lain. Mangkunegara (2005;143) juga mengatakan organisasi pada operasi yang berbudaya kuat akan mencapai kinerja maksimal dan mampu memberi citra positif bagi perkembangan koperasi sehingga diperlukan penerapan budaya organisasi yang berlandaskan pada moral. Dengan demikian, budaya organisasi memiliki hubungan yang bersifat positif terhadap kinerja karyawan.

\section{Gaya Kepemimpinan}

Kepemimpinan adalah bentuk kemampuan untuk mempengaruhi kelompok dalam mencapai tujuan organisasi (Robbins, dalam Bangun, 2012;337). Seorang pemimpin memiliki gaya, model, atau ciri tersendiri untuk menjalankan organisasi sesuai dengan kondisi dan bagaimana caranya memimpin.

Gaya kepemimpinan adalah cara pemimpin untuk mempengaruhi perilaku bawahan agar bekerja lebih produktif (Hasibuan, dalam Bakara dan Sukiswo 2015:10). Sedangkan menurut Swamy (dalam Bakara dan Sukiswo 2015:11) mengatakan bahwa gaya kepemimpinan merupakan proses dimana seorang pemimpin secara sosial mempengaruhi dan berusaha mencari partisipasi bawahan dalam upaya mencapai tujuan organisasi.
Menurut Bangun (2012;347) teori gaya kepemimpinan dengan pendekatan kontingensi terbagi menjadi model fiedler, model situasional (Harley dan Blanchard), model pertukaran pemimpin-anggota, model jalur-sasaran, dan model partisipasi-pemimpin. Faktor dari gaya kepemimpinan situasional tergantung dari situasi yakni kepemimpinan direktif, kepemimpinan suportif, kepemimpinan partisipatif, dan kepemimpinan berorientasi pada prestasi. Menurut Anwar $(2015 ; 191)$ ada beberapa indikator gaya kepemimpinan situasional yaitu penjelasan pimpinan pada karyawan, perhatian pimpinan pada karyawan, permberian kesempatan pada karyawan, dan penghargaan pada karyawan.

Hubungan gaya kepemimpinan terhadap kinerja karyawan. Gaya kepemimpinan menurut Prasetyo (dalam Nisa, 2017;20) mendefinisikan gaya kepemimpinan sebagai bentuk dan perilaku untuk mengintegrasikan antara tujuan organisasi dengan tujuan individu sesuai dengan keinginan. Seseorang yang dapat memengaruhi kinerja dari sebuah organisasi tergantung pada bagaimana peran seorang pemimpin melakukan aktivitas kepemimpinan (Bangun, 2012;36). Dengan demikian, gaya kepemimpinan memiliki hubungan bersifat positif terhadap kinerja karyawan.

\section{Kinerja}

Kinerja karyawan dapat dijadikan dasar dalam peningkatan atau promosi pekerjaan, mutasi, pemberhentian kerja, dan kompensasi. Kinerja perwujudan dari kemampuan membentuk karya nyata atau hasil kerja yang dicapai karyawan dalam menyelesaikan tugas dan pekerjaan organisasi, jadi kinerja bukan termasuk dari karakteristik individu seperti kemampuan atau bakat.

Kinerja adalah hasil pekerjaan yang dicapai seseorang berdasarkan pernyataan pekerjaan (Bangun, 2012;231). Sedangkan Rivai dan Sagala (dalam Priansa, 2016;269) mengatakan kinerja adalah perilaku nyata yang ditampilkan seseorang sebagai prestasi kerja oleh karyawan sesuai dengan peran dalam organisasi. Bangun (2012;235) menyatakan dimensi dari kinerja karyawan terbagi menjadi 3 kriteria yaitu kriteria berdasarkan sifat, kriteria berdasarkan perilaku, dan kriteria berdasarkan hasil. Indikator kinerja karyawan meliputi jumlah pekerjaan, kualitas pekerjaan, ketepatan waktu, kehadiran, dan kemampuan kerjasama.

Sehubungan dengan latar belakang dan tinjauan literatur, maka artikel ini bertujuan untuk 
p-ISSN 1693-1378

e-ISSN 2598-9952
Meningkatkan Kinerja Karyawan Melalui... (Sukaris, Mayang Putri Prathiwi, Budiyono Pristyadi) mengungkap peningkatan kinerja melalui keterikatan karyawan, budaya organisasi dan gaya kepemimpinan.

\section{Hipotesis}

Hipotesis diajukan sebagai jawaban atau dugaan sementara dari suatu permasalahan. Adapun hipotesis yang diajukan dalam penelitian adalah :

$\mathrm{H}_{1}$ : Keterikatan karyawan berpengaruh terhadap kinerja karyawa tetap Koperasi Warga Semen Gresik

$\mathrm{H}_{2}$ : Budaya organisasi berpengaruh terhadap kinerja karyawan tetap Koperasi Warga Semen Gresik

$\mathrm{H}_{3}$ : Gaya kepemimpinan berpengaruh terhadap kinerja karyawan tetap Koperasi Warga Semen Gresik

\section{METODE PENELITIAN}

Penelitian ini menggunakan pendekatan kuantitatif yang dilakukan pada Koperasi Warga Semen Gresik sebagai obyek penelitian. Populasi yang digunakan yaitu 144 karyawan tetap KWSG dengan sampel penelitian sebanyak 108 responden yang diperoleh dari table krejcie untuk menentuka jumlah sampel.

Teknik pengambilan sampel menggunakan probability sampling yakni memberikan peluang yang sama bagi anggota populasi dengan penentuan sampel menggunakan simple random sampling. Variabel penelitian terdiri dari variabel keterikatan karyawan $\left(\mathrm{X}_{1}\right)$, budaya organisasi $\left(\mathrm{X}_{2}\right)$, dan gaya kepemimpinan $\left(X_{3}\right)$ sebagai variabel bebas, serta kinerja karyawan $(\mathrm{Y})$ sebagai variabel terikat.

Definisi operasional variabel pada penelitian yaitu sebagai berikut: Keterikatan karyawan $\left(X_{1}\right)$ adalah keadaan seorang karyawan yang merasa terikat dan terlibat secara langsung, baik fisik maupun emosional dengan perusahaan sehingga ingin memberikan kinerja terbaik bagi perusahaan. Budaya organisasi (x2) nilai-nilai yang diterapkan di perusahaan sebagai pembeda dari organisasi lain dan pembentuk identitas yang bertujuan untuk mempengaruhi perilaku atau karakteristik karyawan di perusahaan. Gaya kepemimpinan adalah cara seseorang atau pemimpin untuk mengarahkan dan mempengaruhi bawahan agar mau bekerja sama untuk mencapai tujuan organisasi. Kinerja karyawan $(\mathrm{Y})$ adalah hasil kerja dari seseorang atau karyawan dalam kurun waktu tertentu pada saat menyelesaikan tugas yang diberikan sesuai dengan kriteria.
Jenis data yang digunakan adalah data primer dari pembagian kuesioner pada karyawan tetap KWSG. Instrumen penelitian menggunakan skala likert dengan pemberian skor 1 untuk jawaban sangat tidak setuju sampai skor 5 untuk jawaban sangat setuju dari item pernyataan yang dijadikan kuesioner.

Teknik analisis data menggunakan uji instrumen, uji asumsi klasik, serta uji hipotesis dengan software SPSS 21 serta analisis regresi linier berganda.

\section{PEMBAHASAN}

Koperasi Warga Semen Gresik atau biasa disingkat menjadi KWSG merupakan koperasi yang juga termasuk milik PT Semen Gresik (Persero) Tbk. KWSG mulai didirikan sejak 29 Januari 1963 dengan nama Koperasi Serba Usaha Karyawan Perusahaan Negara Semen Gresik. Tahun 2011, KWSG menambah bisnis manufacture dengan dibukanya Pabrik Fiber Cement Board. Bidang usaha yang dijalankan semakin bertambah sehingga KWSG mendapat penghargaan tingkat nasional yaitu "excellent of the year 2011" dari International Business \& Company Award 2011.

KWSG kemudian ditunjuk sebagai distributor Semen Gresik karena menunjukkan kinerja yang meningkat, sehingga usaha perdagangan bahan bangunan yang bergerak di bidang perindustrian Semen Gresik dan produk bangunan lainnya berjalan dan berkembang pesat dalam kurun waktu 20 tahun. Tahun 2012, KWSG memiliki 75 cabang di Indonesia yang memiliki 5.954 anggota yang terdiri dari 14 anggota dari anak usaha PT Semen Gresik Indonesia (Persero) Tbk di tahun 2013. KWSG termasuk dalam koperasi terbaik dengan rangking 233 di dunia pada ajang International Cooperative Aliance (ICA) Global 300 di tahun 2011 karena mampu bersaing di tingkat Internasional.

Pengujian atas instrumen yang digunakan dalam penelitian ini menunjukkan bahwa instrumen menunjukkan validitas dan reliabilitasnya. Sedangkan pengujian dengan asumsi klasik atau uji ekonometrika bahwa data sebagai representasi variabel menunjukkan tidak terjadinya bias atau data yang diperoleh tidak terjadi multikoloniritas, tidak terjadi autokorelasi, tidak terjadi heterokedastisitas, dan data bersifat normal.

Penelitian ini menggunakan analisis regresi linier berganda dan uji koefisien determinasi (R2) Adapun rumus regresi linier berganda yang digunakan adalah sebagai berikut : 


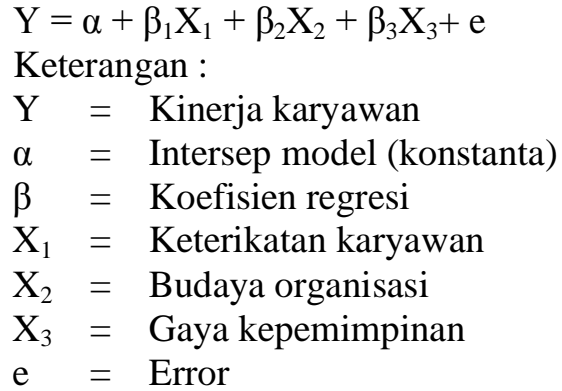

Uji hipotesis menggunakan uji signifikansi parameter individu (uji t). Dasar pengujian hipotesis (Ghozali, 2009) yaitu:

1. Menentukan hipotesis statistik

Ho: $\quad \beta_{1}=0$ artinya variabel keterikatan karyawan $\left(\mathrm{X}_{1}\right)$ tidak berpengaruh terhadap variabel kinerja karyawan tetap (Y).

Ha: $\quad \beta_{1}=0$ artinya variabel keterikatan karyawan $\left(\mathrm{X}_{1}\right)$ berpengaruh terhadap variabel kinerja karyawan tetap (Y).

Ho: $\beta_{2}=0$ artinya variabel budaya organisasi $\left(\mathrm{X}_{2}\right)$ tidak berpengaruh terhadap variabel kinerja karyawan tetap $(\mathrm{Y})$.

Ha: $\beta_{2}=0$ artinya variabel budaya organisasi $\left(\mathrm{X}_{2}\right)$ berpengaruh terhadap variabel kinerja karyawan tetap $(\mathrm{Y})$.

Ho: $\beta_{3}=0$ artinya variabel gaya kepemimpinan $\left(\mathrm{X}_{3}\right)$ tidak berpengaruh terhadap variabel kinerja karyawan tetap $(\mathrm{Y})$.

Ha : $\beta_{3}=0$ artinya variabel budaya organisasi $\left(\mathrm{X}_{3}\right)$ berpengaruh terhadap variabel kinerja karyawan tetap $(\mathrm{Y})$.

2. Menentukan taraf signifikansi Penelitian menggunakan taraf signifikansi $(\alpha)$ sebesar 5\% atau 0,05 dengan pengujian dua arah (2-tailed) dengan rumus: $\mathrm{df}=\mathrm{n}-2$

3. Penentuan kriteria pengambilan keputusan Apabila $\mathrm{t}$ hitung $>\mathrm{t}$ tabel atau nilai signifikansi $<\alpha(0,05 \%)$ maka Ho ditolak dan Ha diterima, dan sebaliknya apabila $\mathrm{t}$ hitung $<\mathrm{t}$ tabel atau nilai signifikansi $>\alpha(0,05 \%)$ maka Ho diterima dan Ha ditolak

Penelitian ini bertujuan untuk mengetahui pengaruh keterikatan karyawan, budaya organisasi, dan gaya kepemimpinan terhadap kinerja karyawan pada karyawan tetap Koperasi Warga Semen Gresik. Berdasarkan penelitian dan analisis yang peneliti lakukan menggunakan alat bantu SPSS 21, maka peneliti dapat menginterpretasikan hasil, bahwa dalam pengujian hipotesis secara parsial dengan menggunakan uji antara masingmasingvariabel independen dan variabel dependen.
Berdasarkan pengolahan data yang telah dilakukan, maka diperoleh hasil nilai konstanta 7,513 menunjukkan bahwa jika variabel keterikatan karyawan, budaya organisasi, dan gaya kepemimpinan bernilai 0 , maka besarnya variabel kinerja karyawan sebesar 7,513 satuan. Nilai koefisien regresi variabel keterikatan karyawan sebesar 0,143 menunjukkan jika variabel keterikatan karyawan berubah, maka kinerja karyawan naik sebesar 0,143 dengan asumsi bahwa budaya organisasi dan gaya kepemimpinan nilainya tetap. Nilai koefisien regresi variabel budaya organisasi sebesar 0,214 menunjukkan jika variabel budaya organisasi berubah, maka kinerja karyawan naik sebesar 0,214 dengan asumsi bahwa keterikatan karyawan dan gaya kepemimpinan nilainya tetap. Nilai koefisien regresi variabel gaya kepemimpinan sebesar 0,046 menunjukkan jika variabel gaya kepemimpinan berubah, maka kinerja karyawan naik sebesar 0,046 dengan asumsi bahwa keterikatan karyawandan budaya organisasi nilainya tetap.

Uji koefisien determinasi menghasilakan Nilai Adjusted R Square 0,263 dapat dijelaskan bahwa perubahan variabel kinerja karyawan sebesar 26,3\% disebabkan oleh variabel keterikatan karyawan, budaya organisasi, dan gaya kepemimpinan. Sedangkan sisanya $73,7 \%$ dapat dijelaskan dari faktor-faktor lain diluar variabel tersebut.

\section{Tabel 1}

\section{Pengujian Hipotesis}

\begin{tabular}{ccccccc}
\hline & \multicolumn{3}{c}{ UC } & SC & & \\
\cline { 2 - 4 } Model & B & $\begin{array}{c}\text { Std. } \\
\text { Error }\end{array}$ & Beta & Sig. \\
\cline { 2 - 5 } (Constant) & 7,513 & 2,341 & & 3,729 &, 000 \\
\hline X1 &, 143 &, 059 &, 222 & 2,440 &, 016 \\
X2 &, 214 &, 051 &, 385 & 4,221 &, 000 \\
X3 &, 046 & 0,065 &, 061 &, 714 &, 477 \\
\hline
\end{tabular}

Keterangan:

UC: Unstandardized Coefficients

SC: Standardized Coefficients

Sumber: Data diolah

Berdasarkan hasil pengujian yang telah sebagaimana disajikan tabel 1: diperoleh t hitung sebesar 2,440>t tabel sebesar 1,983 dengan signifikansi 5\%, maka terbukti bahwa variabel keterikatan karyawan berpengaruh signifikan terhadap Kinerja Karyawan. Hal ini sesuai dengan teori Robbins dan Judge $(2009 ; 103)$ mengatakan bahwa keterikatan karyawan adalah keterlibatan keterlibatan individu dengan kepuasan dan 
p-ISSN 1693-1378

e-ISSN 2598-9952
Meningkatkan Kinerja Karyawan Melalui... (Sukaris, Mayang Putri Prathiwi, Budiyono Pristyadi) antusiasme untuk pekerjaan yang dilakukan sehingga karyawan akan terlibat secara fisik, kognitif dan emosional selama menunjukkan kinerjanya.

Berdasarkan hasil pengujian hipotesis yang telah dilakukan dan diperoleh $\mathrm{t}$ hitung sebesar sebesar 4,221>t tabel sebesar 1,983 dengan signifikansi 5\%, maka terbukti bahwa variabel budaya organisasi berpengaruh signifikan terhadap Kinerja Karyawan. Hal tersebut didukung pernyataan menurut Mangkunegara (2005;143) bahwa organisasi pada koperasi yang berbudaya kuat akan mencapai kinerja maksimal dan mampu memberi citra positif bagi perkembangan koperasi sehingga diperlukan penerapan budaya organisasi yang berlandaskan pada moral.

Berdasarkan hasil pengujian yang telah dilakukan dan diperoleh $\mathrm{t}$ hitung sebesar sebesar $0,714<\mathrm{t}$ tabel sebesar 1,983 dengan signifikansi $5 \%$, maka tidak terbukti bahwa variabel gaya kepemimpinan berpengaruh signifikanterhadap kinerja karyawan. Bangun (2012;337) menyatakan bahwa kepemimpinan adalah bentuk kemampuan untuk mempengaruhi kelompok dalam mencapai tujuan organisasi. Penelitian yang dilakukan memberikan hasil penelitian yang bertolak belakang dengan penelitian yang dilakukan Khairizah, (2015) yang mengatakan bahwa gaya kepemimpinan direktif memiliki pengaruh positif terhadap kinerja karyawan, hal ini juga dapat dimaknai kurang jelasnya visi pimpinan pada karyawan, kurangnya perhatian, kepemimpinan yang belum memberikan perlakuan yang setara pada bawahan dan juga pimpinan belum mampu memberikan penghargaan pada karyawan.

\section{PENUTUP}

\section{Kesimpulan}

Berdasarkan hasil penelitian tentang pengaruh keterikatan karyawan, budaya organisasi, dan gaya kepemimpinan terhadap kinerja karyawan (studi pada karyawan tetap Koperasi Warga Semen Gresik), maka dapat disimpulkan:1) Keterikatan karyawan berpengaruh signifikan terhadap kinerja karyawan tetap Koperasi Warga Semen Gresik; 2) Budaya organisasi berpengaruh signifikan terhadap kinerja karyawan tetap Koperasi Warga Semen Gresik; dan 3) Gaya kepemimpinan tidak berpengaruh signifikan terhadap kinerja karyawan tetap Koperasi Warga Semen Gresik.

\section{Keterbatasan dan Rekomendasi untuk Penelitian Selanjutnya}

Terkait dengan hasil penelitian, pembahasan, dan kesimpulan yang ada pada penelitian ini, maka peneliti memberikan rekomendasi penelitian sebagai berikut: Bagi Koperasi Warga Semen Gresik dapat melakukan kegiatan atau aktifitas yang dapat dijadikan alternatif seperti pemimpin memberi instruksi yang jelas pada saat memberi tugas, pemimpin seharusnya mampu menjelaskan dengan detail apa dan bagaimana tugas yang harus dikerjakan karyawan, keluhan yang disampaikan karyawan hendaknya dapat diterima dan dijadikan sebagai saran bagi pemimpin, pemimpin dapat menumbuhkan minat kerja karyawan dengan berbagai cara seperti memberikan motivasi atau penghargaan, pemimpin berpartisipasi dalam komunikasi tanpa membedakan status antar karyawan, diskusi dengan karyawan sebaiknya dilakukan dengan cara terbuka sehingga dapat mencapai kesepakatan bersama, pemimpin sebaiknya juga mendukung karir karyawan yang kurang menunjukkan prestasi kerja sehingga menjadi motivasi bagi karyawan, diperlukannya perhatian yang diberikan pemimpin pada bawahan yang kinerjanya kurang optimal dapat dilakukan dengan cara memberi motivasi atau punishment yang bersifat positif. Bagi peneliti selanjutnya dapat menggunakan gaya kepemimpinan teori gaya kepemimpinan seperti gaya kepemimpinan transformasional dikarenakan pemimpin transformasional mampu membuat bawahan menyadari perspektif yang lebih luas, sehingga kepentingan individu akan bersama-sama dikoordinasikan terhadap kepentingan tim, organisasi, atau kepentingan yang lebih luas.

\section{DAFTAR PUSTAKA}

Akbar, Muhammad Riza. 2013, Pengaruh Budaya Organisasi Terhadap Employee Engagement (Studi pada Karyawan PT Primatexco Indonesia di Batang). Journal of Social and Industrial Psychology - Fakultas Psikologi, ISSN 2252-6838, hal. 11-14, retrivied from Unnes Journals.

Alkusani, A., \& Sukaris, S. 2019. Pengaruh JobEngagement Terhadap Perilaku Withdrawal Melalui Komitmen Organisasi. Jurnal Riset Entrepreneurship, 2(1), 43-51.

Anwar. 2015. Karakteristik Gaya Kepemimpinan Biro Administrasi Universitas Hasanuddin Makasssar. Jurnal Sosial Ilmu Politik Univeristas Hasanuddin, Vol 1, No. 2, Desember. 
Bakara dan Suskiswo. 2015, Pengaruh Gaya Kepemimpinan terhadap Kinerja Karyawan pada Hotel Travellers Suites Medan, ILMAN, Vol. 3, No.1, Februari.

Bangun, Wilson, 2012. Manajemen Sumber Daya Manusia, Erlangga, Jakarta.

Handoyo, Agnes Wahyu dan Setiawan, Roy. 2017, Pengaruh Employee Engagement Terhadap Kinerja Karyawan pada PT Tirta Rejeki Dewata. AGORA, Vol. 5, No. 1.

Hasibuan, M. 2011, Manajemen Dasar, Pengertian, dan Masalah. Jakarta, PT. Bumi Aksara.

Joushan, Syamsun, Kartika. 2015. Pengaruh Budaya Organisasi dan Employee Engagement Terhadap Kinerja Karyawan pada PT PLN (Persero) Area Bekasi, Jurnal Aplikasi Manajemen, Vol. 13, No. 4, Nopember.

Khairizah, A. 2015. Pengaruh Gaya Kepemimpinan Terhadap Kinerja Karyawan (Studi pada Karyawan di Perpustakaan Universitas Brawijaya Malang). Jurnal Administrasi Publik, 3(7), 1268-1272.

Kruse, 2012. What is Employee Engagement. Forbes Leadership.

Mangkunegara, Anwar Prabu. 2005. Perilaku dan Budaya Organisasi, Cetakan kesatu, Refika Aditama, Bandung.

Nisa, Zahrotun. 2017. Pengaruh Gaya Kepemimpinan, Disiplin, Motivasi, dan Pendidikan Terhadap .Kinerja Guru SMA Muhammadiyah 1 Gresik. Skripsi. Manajemen. Fakultas Ekonomi dan Bisnis. Universitas Muhammadiyah Gresik.
Priansa, Donni Juni. 2016. Perencanaan dan Pengembangan SDM. Alfabeta, Bandung

Rivai, Veithzal dan Sagala, Ella Jauvani. 2011. Manajemen Sumber Daya Manusia Untuk Perusahaan. Edisi ke-2. Jakarta, Rajawali Pers

Robbins, S. P., and Judge, T. A. 2009. Organisational behaviour. 13th (ed) USA.

Robbins, S. P., and Judge, T. A. 2015. Organization Behavior. Kendallville: Global Edition.

Rustono, Anton dan Akbari. 2015. Pengaruh Employee Engagement Terhadap Kinerja Karyawan Dana Pensiun (Dapen) Telkom Bandung, e-proceeding of Management, Vol. 2, No. 2.

Schiemann, William A. 2011. Alignment, Capability, Engagement. Jakarta: Penerbit PPM.

Siddhanta, A., and Roy, D. 2010. Employee engagement engaging the 21 st century workforce.

Sukaris, S. 2018. Kajian Empiris Dalam Pemosisian Produk. Jurnal Riset Entrepreneurship, 1(2), 1-12.

Zahriyah, Utami dan Ruhana. 2015. Pengaruh Budaya Organisasi Terhadap Kinerja Karyawan. Jurnal Administrasi Bisnis (JAB), Vol. 2, No. 1, Februari.) 